\title{
Improving brassica crop yields in areas cultivated out of hawkweed
}

\author{
P.D. McGIMPSEY ${ }^{1}$, R.G. DUFFY ${ }^{2}$ and B.S. McCUTCHEON ${ }^{3}$ \\ ${ }^{1}$ Ravensdown Fertiliser Co-op Ltd, P 0 Box 179, Alexandra \\ ${ }^{2}$ Private Consultant, 1 I Bedford Parade, Brighton, Dunedin \\ 3 Wrightson, Private Bag 1966, Dunedin
}

\section{Abstract}

Hawkweeds (Hieracium species) presently dominate 500000 ha of the South Island high country. Their spread threatens the ecology of the tussock grasslands and the livelihood of runholders. Management practices have been partially successful at controlling hawkweed spread, but increasingly runholders are cultivating suitable areas. Crops planted into this environment are usually poor with negligible yield. Over 2 seasons 5 trials investigated the role of nitrogen, lime and molybdenum, boron superphosphate in the growth of soft turnips (Brassica campestris ssp. rapifera Green Globe) and Italian ryegrass (Lolium multiflorum). The results showed the importance of nitrogen. The nitrogen response of total yield was curvilinear or linear in every trial. Up to $48 \mathrm{~kg}$ DM/kg N was grown when $80 \mathrm{~kg}$ N/ha was applied, There was no significant reponse to molybdenum, boron, superphosphate or lime. Vegetation and soils dominated by hawkweeds are low in nitrogen, therefore little nitrogen is released after cultivation.

Keywords:-crop-yields-dryland,-Hieracium pilosella, nitrogen, toe slopes, Brassica campestris ssp. rapifera, tussock grasslands, Lolium multiflorum

\section{Introduction}

The use of large areas of tussock grassland which support significant wool, beef, prime and store lamb production in the South Island is threatened by hawkweed (Hieracium pilosella) incursion. Recent estimates indicate that 500000 ha are dominated by hawkweed, and in a further one million ha they are conspicuous (McMillan 1991; Hunter 1991). Otago and Canterbury contain the bulk of the hawkweed-dominated country. The toe slopes of the ranges provide the majority of the grazing. Because of their strategic value within properties, hawkweed dominance of toe slopes has a strong influence on the viability of the properties. Livestock are unable to extract enough nutrient from hawkweeds for maintenance needs. As a result an estimated 500000 stock units have been lost from the high country (McMillan 1991; Hunter 1991; Kerr 1992).
Presently the best means of avoiding hawkweed dominance is to establish and maintain a vigorous and dense pasture cover. Run-holders now seek methods which slow the spread of hawkweeds and increase profitability.

Options available to them include oversowing and topdressing, and direct drilling. Results are only partially successful due to re-invasion of hawkweeds. In low rainfall areas hawkweeds continue to spread even in well-managed grasslands, presumably because of the length of dry periods. In well-maintained wetter areas hawkweeds spread whenever there is a prolonged dry period or when economics make it difficult to justify fertiliser input.

As runholders seek solutions, increasingly they look towards traditional cultivation to pasture. First- and second-year brassica crops planted in these circumstances are usually of poor quality and negligible yield, with pastures often slow to establish. Earlier work identified soil $\mathrm{pH}$, nitrogen, phosphorus, sulphur, molybdenum, and boron as most limiting production in the South Island high country (Walker et al. 195.5; Ludecke 1962; Floate \& Enright 1991; Floate et al. 1987; Sinclair \& Floate 1984). Cossens (1982) summarised the-results-of-brassica-trials-in-Otago-and found significant responses to phosphorus and nitrogen.

This paper describes the responses of turnips and Italian ryegrass to applied nitrogen, lime and superphosphate with molybdenum, and boron over two seasons.

\section{$M$ aterials and methods}

Field trials were carried out in the Paerau district of the Maniototo in both the 1992193 and 1993194 seasons. The trials were all 2 X 4 randomised factorials with 4 replicates. There were $\mathbf{5}$ trials over the two seasons. Fertiliser treatments in each trial are outlined in Table 1. Seeding rate for all trials was $1 \mathrm{~kg} / \mathrm{ha}$ turnips (Brassica campestris ssp. rapifera Green Globe) and $6 \mathrm{~kg} / \mathrm{ha}$ Italian ryegrass (Lolium multiflorum), broadcast on, except in trial 2 when turnips alone were sown. The climate at both sites was similar with annual rainfall of $600-800$ $\mathrm{mm}$. Cold winters and mild summers provide only a 6month growing season. Because it is local practice, a basal application of $375 \mathrm{~kg} / \mathrm{ha}$ moly boron superphosphate was applied to all plots each year. 
Table 1 Treatments applied to trials 1-5.

\begin{tabular}{|c|c|c|c|c|c|c|}
\hline \multirow[b]{2}{*}{$\begin{array}{l}\text { Treatment } \\
\text { (Vha) }\end{array}$} & \multicolumn{2}{|c|}{ Trials ! and 2} & \multicolumn{2}{|c|}{ Trial 3 and 4} & \multicolumn{2}{|c|}{ Trial 5} \\
\hline & $\begin{array}{c}\text { Lime } \\
\text { (kg N/ha) }\end{array}$ & $\begin{array}{c}\text { Nitrogen } \\
\text { (t/ha) }\end{array}$ & $\begin{array}{c}\text { Lime } \\
\text { (kg N/ha) }\end{array}$ & $\begin{array}{c}\text { Nitrogen } \\
\text { Form }\end{array}$ & $\underset{(\mathrm{kg} / \mathrm{ha})}{\mathrm{N}}$ & 0.9 .0 \\
\hline 2 & $\begin{array}{l}0 \\
0\end{array}$ & 20 & $\begin{array}{l}0 \\
0\end{array}$ & $\begin{array}{l}0 \\
40\end{array}$ & $\begin{array}{c}\text { Urea } \\
\text { AmmSul }\end{array}$ & $\begin{array}{l}0 \\
0\end{array}$ \\
\hline 3 & 0 & 40 & 0 & 80 & Urea & 125 \\
\hline 8 & 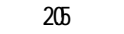 & $\$ 0$ & 205 & 180 & Ardmesul & 250 \\
\hline 6 & 2.5 & 20 & 2.5 & 40 & AmmSul & 250 \\
\hline 7 & 2.5 & 40 & 2.5 & 80 & Urea & 500 \\
\hline 8 & 2.5 & 80 & 2.5 & 120 & AmmSul & 500 \\
\hline
\end{tabular}

Trial 5: Examined the influence of rate of superphosphate and form of nitrogen on yield. Nitrogen was applied at a rate of 80 $\mathrm{kg} \mathrm{N} / \mathrm{ha}$. This site had been cultivated for 2 seasons.

Harvesting was carried out in May when growth had stopped. Plots were cut and weighed, with subsampens fordry matter determination.

Initial soil sample results are presented in Table 2.

\section{$1992 / 93$ season}

Trials 1 and 2 were laid down in November 1992..

Trial 1: Located on Rocklands Station, this site was at $485 \mathrm{~m}$ altitude, facing north-west on the eastern side of the Rock and Pillar range. The soil was a Middlemarch yellow-grey earth. This site was ploughed in autumn 1992, and after a winter fallow, was disced into a seed-bed in the spring prior to sowing. With a history of grazing and periodic burning, the block had had minimal inputs. Cover was estimated at $\mathbf{7 0 - 8 0 \%}$ hawkweed with remnants of hard or silver tussock (Festuca novae zelandiae).

Trial 2: Located at Eric and Cate Laurenson's property. This site was at $580 \mathrm{~m}$ altitude in a topographical basin facing north east. The soil was a Pukerangi yellow-grey earth, with a history of low-input extensive grazing. This site was bush and bog disced in the autumn, then cultivated to a seed-bed in spring. The cover consisted of $80 \%$ hawkweed with some remnants of hard or silver tussock.

\section{4 season}

Three trials were laid down in November 1993. All were located on the Larenson property on the same site as Trial 2.

Trial 3: Laid on top of trial 2 from the $1992 / 93$ season, with the difference that the lowest rate of nitrogen was replaced by a higher rate of nitrogen. The lowest rate of nitrogen was $40 \mathrm{~kg} / \mathrm{ha}$ and that was laid on the plots which had $20 \mathrm{~kg} / \mathrm{ha}$ in trial 2. No additional lime was applied. This site had therefore been cultivated for 2 seasons.

Trial 4: Located on a site that was cultivated in the autumn of 1993, and cultivated into a seed bed prior to sowing in the spring.
Table 2 Initial soil test results.

\begin{tabular}{lcccccc}
\hline & $\mathrm{pH}$ & $\mathrm{Ca}$ & $\mathrm{P}$ & $\mathrm{K}$ & $\mathrm{S}$ & $\mathrm{Mg}$ \\
\hline Rocklands & 5.0 & 4 & 20 & 8 & 2 & 20 \\
Laurenson & 5.0 & 3 & 16 & 9 & 2 & 23
\end{tabular}

Table 3 Economic analysis of trial 1.

\begin{tabular}{lrrrr}
\hline Rate of nltrogen kg/ha & 0 & 20 & 40 & 80 \\
Cultivation \& seed \$/ha & 230 & 230 & 230 & 230 \\
Fertiliser \$/ha & 100 & 125 & 150 & 200 \\
Total cost/ha & 330 & 355 & 380 & 430 \\
Total DM kg/ha & 883 & 1633 & 2493 & 4666 \\
Costs c/kg DM & 37 & 21 & 15 & 9 \\
\$/bale equivalent & 7.40 & 4.20 & 3.00 & 1.80 \\
(20 kg DM standard bale) & & & & \\
\hline
\end{tabular}

\section{Results}

Increasing rates of nitrogen applied gave increasing total dry matter yields over all the nitrogen treatments applied in trials 1, 2, 3, and 4. Figure 1 demonstrates a significant $(\mathbf{P}<0.01)$ quadratic response to nitrogen in Trial 1. Figures 3 and 4 show the significant $(\mathbf{P}<0.01)$ responses obtained in trials 3 and 4 respectively. The response curves are quadratic in trial 3 and linear in trial 4.

In trial 2 (Figure 2) no Italian ryegrass was sown. Because rabbits ate the turnip tops no harvesting was possible. However bulbs were undamaged and were harvested.

Increasing rates of nitrogen applied gave increasing yields of turnip bulbs, over all rates of nitrogen applied in trials 1-4 ( Figs. 1-4 ).

There were no significant responses in trial 5 .

\section{Discussion}

Nitrogen has had a positive impact on yields. Hawkweed vegetation is very low in plant nutrients, particularly 
Figure 1 Nitrogen response trial 1.

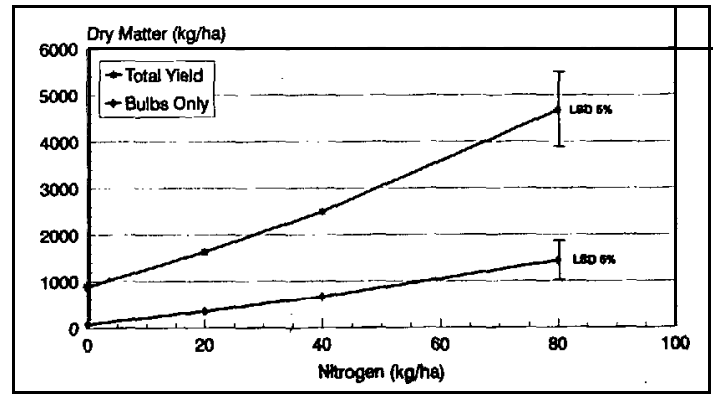

Figure 3 Nitrogen response trial 3.

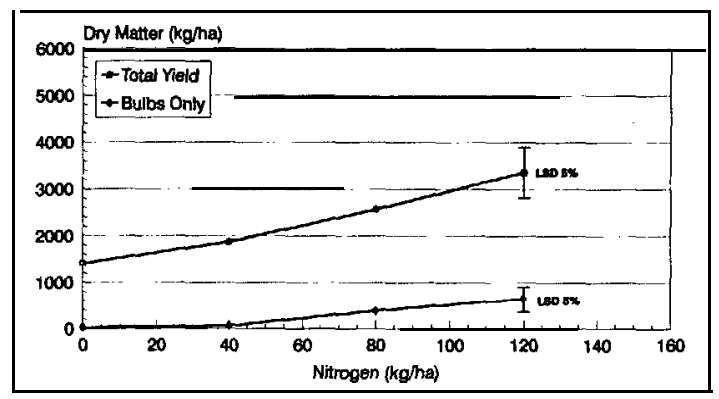

nitrogen, compared with other plant communities in this environment (Nordmeyer 1993, unpublished data). After cultivation, therefore, less nutrient can be expected to be released from the plant material for recycling into the new soil/plant environment.

The initial soil test results, particularly sulphur levels and soil $\mathrm{pH}$, suggest that the soils used in these trials are in a depleted state. However, phosphate levels, as shown by Olsen $\mathrm{P}$, were in the optimal range.

The trial results illustrate the importance of adding nitrogen when crops are established in this environment. The curvilinear response curve in Figure 1 demonstrates that responses to nitrogen applied at rates higher than $80 \mathrm{~kg} \mathrm{~N} / \mathrm{ha}$ may be expected. At Rocklands $20 \mathrm{~kg} \mathrm{~N} / \mathrm{ha}$ resulted in $37 \mathrm{~kg} \mathrm{DM} / \mathrm{kg} \mathrm{N}$ applied, while $49 \mathrm{~kg} \mathrm{~N} / \mathrm{ha}$ yielded $40 \mathrm{~kg} \mathrm{DM} / \mathrm{kg} \mathrm{N}$ and $80 \mathrm{~kg} \mathrm{~N} / \mathrm{ha}$ yielded $47 \mathrm{~kg}$ DM/kg N. The responses in Figures 2, 3 and 4 also indicate that $120 \mathrm{~kg} \mathrm{~N} / \mathrm{ha}$ is less than the biological optimium. Yields were lower in trials 3 and 4, owing to higher summer rainfall, lower soil temperatures and quality of the seed-bed at planting.

Nitrogen responses of this magnitude in this environment are recorded in the literature. Cossens (1983) reports responses of between 18 and $50 \mathrm{~kg} \mathrm{DM} /$ $\mathrm{kg} \mathrm{N}$, and also records responses to phosphorus but in conditions of lower soil phosphorus levels than the soils in this study.
Figure 2 Nitrogen response trial 2.

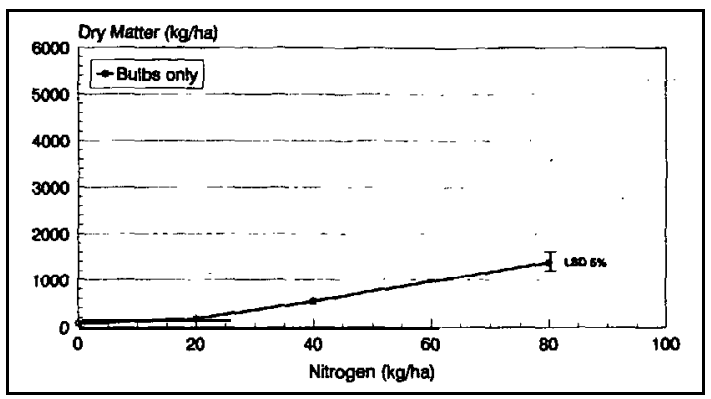

Figure 4 Nitrogen response trial 4.

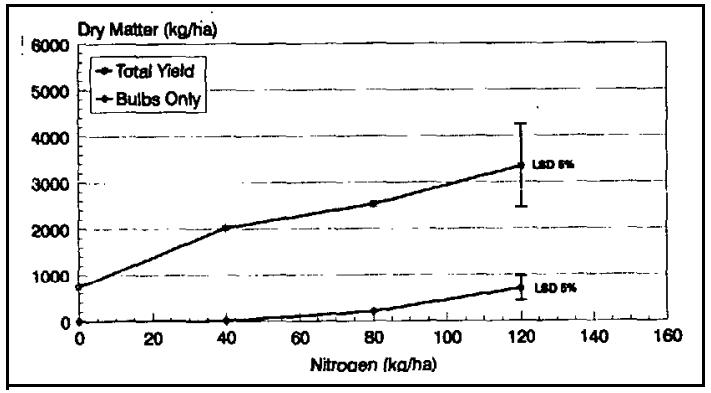

Since the response to lime is long term no response was expected and none was measured. The short growth period of the crop did not allow lime to act prior to harvest. However, a response is expected when the lime has had a chance ${ }^{-} 0^{-}$act $^{-}$when- the-area-is-sown-into young grass.

Trial 5 demonstrated that there was no response to moly boron superphosphate as applied. This supports the premise that the major growth limitation under the treatments of the trial was nitrogen. The role of $\mathrm{P}$ and $\mathrm{S}$ in first-year and second-year crops in this environment is therefore questioned. However, it is likely that they will be important in the establishment and growth of pasture and applications during the years of cropping assists in building up soil reserves.

Grazing by rabbits affected plant growth in trial 2 . It is possible that yields at Laurenson's would have been similar to those at Rocklands had Italian ryegrass been included in the initial mixture and had rabbits been excluded. This is supported by the data in Figures 1 and 2 which show that bulb yields were similar in trials 1 and 2. Italian ryegrass was included in trials $\mathbf{3 , 4}$ and 5 for this reason the following year.

Results obtained from the trials allow feed cost to be compared. Dry matter grown in trial 1 without nitrogen cost $\$ 7.40$ per bale equivalent (standard $20 \mathrm{~kg}$ bale), while the addition of the $80 \mathrm{~kg} \mathrm{~N} / \mathrm{ha}$ results in a 
reduction of that cost to under $\$ 1.80$ per bale (Table 3). Similar trends are also evident in the other trials.

\section{Conclusions}

Nitrogen is the major nutrient limiting plant growth in these trials. Biological maximum yield was not reached in any trial.

The trial results indicate that, provided adequate nitrogen is used, Italian ryegrass and turnips produce dry matter at a lower cost than hay.

Nitrogen should be used in development strategies for low nitrogen fertility sites. Browntop-dominant pastures and areas low in legumes are examples.

\section{ACKNOWLEDGEMENTS}

Mervyn McDonald, Manager Rocklands Station. Bob, Eric and Cate Laurenson,

Wrightson Dunedin staff, David Rowlands, John Craig, Simon Harrex, Rebecca Latter.

Dr Fred Lam, Otago University.

\section{REFERENCES}

Cossens, G.G. 1982. Effects of altitude on cereal, brassica and grass growth in Otago. Proceedings Agronomy Society of NZ 12: 51-56.

Floate, M.J.S.; Enright, P.D. 1991. The economics of tussock grassland pasture improvement. Invermay Technical Report No 27. Invermay Agricultural Centre: 24p.
Floate, M.J.S.; Boswell,C.C.; Allen, B.E.; Scott, D. 1987. Towards 2000: Strategies to achieve more efficient fertiliser use in inland South Island hill and high country. Proceedings of the New Zealand Grassland Association 48: 53-58.

Hunter, G.G. 1991. The distribution of hawkweeds (Hieracium spp.) in the South Island indicating problem status. Journal of the New Zealand Mountain Lands Institute. Review 48: 21-3 1.

Kerr, I.G.C. 1992. The high country in transition some implications for occupiers and administrators. Journal of the New Zealand Mountain Lands Institute. Review 49: 32-50.

Ludecke, T.E. 1962. Formulation of a rational fertiliser programme in tussock country. Proceedings of New Zealand Grassland Association 22: 96- 116.

McMillan, G. 1991. Hawkweed report. Journal of the New Zealand Mountain Lands Institute. Review 48: 8-20.

Sinclair, A.G.; Floate, M.J.S. 1984. Nutrient deficiencies and fertiliser requirements in tussock grassland soils. Proceedings of the High Country Field Day, Tara Hills, March 1984. 49-53.

Walker, T.W.; Adams, A.F.R.; Orchiston, H.D. 1955. The effects and interactions of Sulphur, Phosphorus and Molybdenum on the growth and composition of clovers. NZ Journal of Science and Technology 36A: 470-472. 